\title{
Diagnostics and Monitoring of COVID-19 Infection - Current Understanding
}

\section{Bergant Martina, de Marco Ario}

\author{
Laboratory for Environmental and Life Sciences - University of Nova Gorica, Slovenia \\ *Corresponding author: Ario de Marco, LELS - University of Nova Gorica, Vipavska cesta 13, \\ SI-5000 Nova Gorica, Slovenia. Phone: +386. (0)5.3315295; e-mail: ario.demarco@ung.si
}

\begin{abstract}
The progression of the recent COVID-19 pandemic surprised political authorities as well as scientists. The possibility to design powerful strategies for health care and preserving economic and social activities strongly relies on the capacity to monitor correctly the virus spreading and the immune response in the symptomatic and asymptomatic population. The available data relative to the first pandemic months indicate that the test reliability was progressively improved but also that the extremely variable methodologies used in the diagnostic studies generated data that are often not comparable. This condition prevents a simple metadata analysis for the identification of reliable diagnostics guidelines. Nevertheless, there are converging evidences that combinations of complementary approaches may enable more precise identification of virus infection. Furthermore, it appears that the similarities between SARS-CoV2 and the related types SARS-CoV1 and MERS that caused outbreaks in the last 20 years can be exploited to infer some information for which no direct evidence is still available
\end{abstract}

Keywords: RT-PCR, seroconversion, serum biomarkers, SARS-CoV2, neutralizing antibodies 


\section{Introduction}

The clinical, social and economic impact of the global pandemic caused by SARS-CoV2/COVID19 (1) has promoted a probably unmet global effort to investigate any aspect related to the biology of such virus. The early availability of the complete genome sequence of SARS-CoV2 (Wuhan-Hu-1, GenBank: MN908947) (2) allowed the identification of similarities with the other Coronaviridae and to design the primers for its diagnostic amplification. SARS-CoV2 trafficking into the host cell is primarily driven by the receptor-binding domain (S1) of the spike glycoprotein that apparently forms a homo-trimer to interact with ACE2 receptor (3-9) and, possibly, with CD26 and Ezrin $(10,11)$. The clinical observations suggest that the overexpression of the senescence biomarkers ACE2 and CD26 (12) correlates with stronger infection and this might be one of the reasons for which COVID-19 mortality among elders is extremely higher than in younger population classes (13). It is unknown if younger population is protected also by other specific biological mechanisms of innate immune system. Infected people can apparently spread virus particles for a period of 10-14 days, 1-4 days before and 710 after symptom appearance, although asymptomatic and mild cases could be infective for shorter times (reviewed in 14). The impression is that, despite the existing guidelines, at global level factors such as low processing power, difficulty to access to tests, and apparent incorrect implementation of the available diagnostic methodologies impaired a sufficient sampling of infected patients by means of swab sampling and RNA detection $(15,16)$. As a consequence, there is a critical underestimation of the actual cases and a reduced possibility of effective confinement of infectious COVID-19. The evaluation of the humoral adaptive immunoresponse would represent useful complementary diagnostic information. The available data indicate a prompt seroconversion in COVID-19 patients (17) and a general decrease of the cell-mediated response (18-20). Of course, it is not yet known the long term protective effect of memory cells in the case of SARS-CoV2 but the data relative to SARS-CoV1 immunoresponse showed that almost $90 \%$ of the convalescent patients had a sufficient titer of neutralizing $\operatorname{lgG}$ two years after infection and $50 \%$ preserve it after four years (21). A systematic and repeated analysis of samples from recovered patients and infected but symptomless people will provide the information necessary to elucidate both the 
characteristics of neutralizing antibodies and the long-term protective capacities of humoral immunosystem towards SARS-CoV2. The accomplishment of this objective is instrumental for the design of a robust vaccine. Altogether, there is a strong interest for accurate diagnostics to control population infectivity, contamination and rate of immunoprotection. To collect reliable data it is necessary to know advantages and shortcomings of the different diagnostic methods and to evaluate critically the already available information. This contribution tries to summarize the state-of-the-art of the SASRS-CoV2 diagnostics since no similar effort has been accomplished so far.

\section{Detection of viral RNA}

Accurate diagnosis and efficient monitoring of COVID-19, caused by SARS-CoV2 virus, is strongly dependent on proper specimen collection and sensitive viral RNA detection. While the latter is performed in professional laboratories with increasingly accurate methods and kits which provide reproducible results, the correct collection of specimens in terms of both sampling modality and sampling time remains the upmost critical and uncertain step of the chain. It is known by now that COVID-19 patients have different virus loads at different stages of the disease and progressively shed RNA in different body organs.

SARS-CoV2 and other endemic human coronaviruses (HCoVs) can be detected in both upper and lower respiratory tracts, including nasal and pharyngeal fluid, saliva, sputum, and bronchoalveolar fluid (22) (Figure 1). Detection of viral RNA in the upper respiratory tract samples is usually sufficient for the early identification of COVID-19 infection and upper respiratory specimens are by far the most frequently collected specimens during COVID-19 outbreaks around the world. Such swabs are easy to collect, enable extensive testing of potentially infected individuals, pose a relatively low exposure risk for health care professional and their invasiveness is low. Viral load of SARS-CoV2 in the early stage of the disease is the highest in pharyngeal region, with the detection of viral RNA in nasopharynx (NP) being more sensitive than in oropharynx $(23,24)$. The World Health Organization (WHO) recommends that all patient samples with suspected SARS-CoV2 should be isolated from 
respiratory tract and analyzed by authorized laboratories for diagnostic nucleic acid amplification testing (https://apps.who.int/iris/bitstream/handle/10665/331329/WHO-COVID-19-laboratory2020.4-eng.pdf, 25). Specimens should be stored at $2-8^{\circ} \mathrm{C}$ and shipped promptly to the laboratory, or stored in viral transport medium at $-20^{\circ} \mathrm{C}$ to $-70^{\circ} \mathrm{C}$, if a delay in reaching the laboratory is expected. US centers for disease control and prevention (CDC) recommends collecting the upper respiratory NP swab, with oropharyngeal (OP) and nasal (NS) swabs having lower priority (https://www.cdc.gov/coronavirus/2019-nCoV/lab/guidelines-clinicalspecimens.html, 26). Sensitivity can be improved with the combination of two or more sampling sites, as already emphasized in the discharge criteria for COVID-19 patients. For instance, combination of OP and NS swabs might be a good alternative providing good sensitivity, low invasiveness and still low exposure risk for health workers. Many countries, including EU, USA and China, consider recovered and not infective only patients who show no relevant symptoms and were RT-PCR negative in at least two sequential analyses of respiratory tract samples, collected more than 24 hours apart (https://www.ecdc.europa.eu/sites/default/files/documents/COVID-19-Discharge-

criteria.pdf, 27). At later stages, the viral load in the lower respiratory tract is significantly higher than in the upper respiratory tract $(24,28)$. However, sampling of bronchoalveolar specimens and sputum is technically difficult and appropriate only for seriously ill patients in the intensive care units.

A recent retrospective cohort study from Zhejiang province in China showed that rates of SARS-CoV2 detection in the respiratory samples (saliva and sputum) gradually decreased from $95 \%$ in the first week of the symptom onset to $54 \%$ in the fourth week. The viral load and persistence of virus correlated with the severity of disease. In patients with pneumonia, high viral load can be observed even in the third and fourth week after the disease onset. They have generally longer persistence of SARS-CoV2 in respiratory samples, higher viral load, and a later shedding peak (29). A report describing the reliability of RT-PCR tests repeated on the same patients over a period of few weeks indicates that the viral load drops significantly. After 5 days more than $50 \%$ of the patients resulted negative when naso- and oropharyngeal swabs were used, despite some cases in which the viral RNA could be detected also at the day 
28 post symptom offset (30). Such data confirmed the shortcomings previously noticed for SARS-CoV1 diagnostics and specifically the low sensitivity of RT-PCR performed with NP/OP swab samples collected during late infection stages (31,32).

Sputum samples appear more reliable for RT-PCR and, since viral RNA concentration declines more slowly than in swabs, it can be detected till three weeks after symptoms appearance. Saliva samples are promising non-invasive specimens with high sensitivity for viral RNA detection as well as for the recovery of viable viral particles $(29,33)$. Together with nasal samples, self-collected saliva samples are the most promising target in the development of point-to-care (POC) devices for the fast diagnosis and surveys aimed at monitoring SARS-CoV2 infection spread (34). For patients with pneumonia, lower respiratory tract specimens, such as sputum and bronchoalveolar lavage fluid, are tested in addition to upper respiratory samples. Viral RNA-based detection in the respiratory samples is the most suitable test also for the identification of asymptomatic carriers, which appear to have a prolonged viral shedding in respiratory tract compared to COVID-19 patients (35). Summarizing, respiratory samples are usually very reliable for confirming the infection in the early stage of disease. However, with its advancement, shedding of viral RNA in pharyngeal area declines the fastest, particularly in patients with mild symptoms, and disease can remain undetected in the majority of the cases if tested by RT-PCR one week after symptom onset $(24,35,36)$.

SARS-CoV2 viral RNA can be detected in blood and stool specimens at later stages of the COVID-19 infection. At least part of COVID-19 patients develops systemic viremia with viral RNA detected in blood samples, either in serum or full blood. However, in contrast to the higher rates reported for SARS and MERS, SARS-CoV2 RNA was detected in the sera of less than $30 \%$ of COVID-19 patient with pneumonia, with the peak of detection in the second week of disease and a gradual decrease later on (29,37). Presence of serum viral RNA usually correlates with the disease severity (38). Since SARS-CoV2 can infect the digestive, urinary in addition to the respiratory system and haematological systems, there is the possibility of using stool and urine as complementary samples for the detection of virus particles $(39,40)$. Several studies reported that faecal/anal samples continued being positive for weeks after the respiratory samples turned negative. Faecal specimens have been repeatedly reported positive in COVID-19 patients $(29,38,41-43)$ and viral RNA testing of faecal or anal swabs could 
improve the discharge accuracy and reduce the possibility of faecal-oral transmission. Further studies are needed to elucidate if SARS-CoV2 is viable in stool samples, posing a potential health treat. Zheng at al. (29) detected SARS-CoV2 RNA in the stool samples of 59\% of patients and found that the persistence of virus was present longer, and viral load peaked later, in stool samples compared to respiratory samples. Wu at al. (41) observed that in more than half of the patients, faecal samples remained positive for SARS-CoV2 RNA for a mean of 11.2 days after respiratory tract samples became negative. The period of viral RNA shedding was in some cases extended for nearly 5 weeks after the viral clearance in the respiratory tract. Similar pattern was observed also when collecting rectal swab samples (44), altogether suggesting propagation of viruses in gastro-intestinal track and a possible faecal-oral transmission route although, in contrast to SARS and MERS, no cases of transmission via the faecal-oral route have been reported for COVID-19 so far. It is interesting that prolonged detection of the viral RNA in the faecal samples was associated neither with the presence of gastrointestinal symptoms nor with the disease severity (41).

The take-home message is that it is important to recognize that the detection of virus in infected individuals is strongly affected by the quality of the sampling. The question of how many tests are needed and what kind of specimen should be tested on individual patients, for the primary diagnosis or for the virus clearance confirmation, remains open. Regardless the kind of samples used, standardized sample acquisition, rapid delivery of specimens for analyses, standardized testing procedures and use of guideline-compliant test kits can effectively improve the accuracy of SARS-CoV2 RNA detection.

\section{Methodological approaches}

Molecular based approaches are the first choice in the laboratory diagnosis of SARS-CoV2 infected individuals. Development of molecular methods to detect viral RNA was initiated with an assay developed by the Chinese Center for Disease Control and Prevention (45) when the genomic sequence of SARS-CoV2 was identified and deposited to the gene bank (WuhanHu-1, GenBank Accession No. MN908947). The genome sequence was then used to further design specific primers and probes to detect the SARS-CoV2, mostly by different real-time RT- 
PCR assays ( $r R T-P C R)$. It is worth to be mentioned that SARS-CoV2 tested negative when using pan-CoV molecular panels that detect the endemic human coronaviruses HCoVs (HCoV-NL63, HCoV-HKU1, HCoV-OC43, and HCoV-229E) (46). The first open reading frames (ORF 1a and 1b), RNA-dependent RNA polymerase gene (RdRp), envelope (E), nucleocapsid ( $N$ ) and spike (S) have become key diagnostic targets for SARS-CoV2 identification (reviewed in 47). One of the first validated laboratory tests has been developed by Charité - Universitätsmedizin Berlin (Germany) exploiting genomic data from China as a reference and by coordinating laboratories belonging to a European research network. Diagnostic workflow begins with two RT-PCR assays that detect E and RdRp genes of subgenus Sarbecovirus (SARS-CoV, SARS-CoV2, and bat-associated betacoronaviruses). The second step, performed on positive samples only, is an rRT-PCR screening of the SARS-CoV2 specific RdRp targets (48). This protocol has provided the basis for many others developed later on in different laboratories around the world. After the initial failure of the kit developed by CDC which determined a critical delay in determining the infection impact, systematic tests were organized in USA as well (49).

Recently, WHO considers screening of a single discriminatory target sufficient for areas where SARS-CoV2 is widely spread. For areas with no known SARS-CoV2 circulation, a positive NAAT result for at least two different targets on the SARS-CoV2 genome is recommended, of which at least one target must be specific for SARS-CoV2 and identified using a validated assay. The viable alternative is one positive NAAT result for the presence of betacoronaviruses and further confirmation of SARS-CoV2 by partial or complete sequencing of the viral genome (25). Some authorized institutions have shared their protocols and provided specific sequences of target primers to the WHO public database, which contains also an overview of all SARS-CoV2 tests commercially available or in development for the diagnosis of COVID-19 (https://www.finddx.org/COVID-19/pipeline/). As of May 13, US Food and Drug Administration (FDA) has authorized the emergency use of in vitro diagnostics for detection and/or diagnosis of SARS-CoV2 to 70 commercially test kits and 28 molecular-based tests for exclusive use in the laboratories which developed them (https://www.fda.gov/medicaldevices/emergency-situations-medical-devices/emergency-use-authorizations\#covid19ivd). 
An exhaustive list of commercial kits and protocols under development has been recently published (22).

While the number of diagnostic tests available for SARS-CoV-2 increases, many challenges remain to be solved. Various tests can have considerable variability in the performance (e.g. sensitivity and specificity) with sometimes unspecific/false negative signals and need for ad hoc optimization $(50,51)$. As reported above, sampling conditions (e.g. sampling modalities, different stage of infection) can strongly affect detection of viruses $(23,28,52,53)$ and there is a constant need to monitor test performance given the potential for the virus to mutate. Apart from sensitivity and specificity, short analysis time is crucial to handle large numbers of samples in case of COVID-19 outbreaks or the necessity of large-scale testing campaigns to monitor the infection diffusion in the population. A high throughput method for RT-PCR tested with artificial samples with spiked RNA (54) showed sensitivity close to results reported by Corman et al. (48) but its validation with biological samples is not yet available. In parallel with qualitative assays, there would be also the need for standardized RNA quantification to provide reliable information on the actual viral load that would be very useful to monitor level of infectivity, recovery and/or response to therapy (34).

\section{Serum biomarkers}

Several articles report the concentrations of soluble serum parameters in the search of molecules which could have diagnostic values. The content of biomarkers such as lactose dehydrogenase, D-dimer and CRP (C-reactive protein) was quantified together with RNA (55) and resulted significantly increased in almost half of the samples recovered from 24 asymptomatic COVID-19-positive cases. Other reports confirmed that, in patients with symptoms, the disease onset correlates with increased blood concentrations of inflammatory cytokines, creatinine, urea nitrogen, lactate hydrogenase, angiotensin II, D-dimer and CRP, the content of which might represent complementary biomarkers for understanding the disease development in COVID-19 patients (18,56-60). It must be underlined that serum analyses were limited in number and performed neither systematically nor repeatedly during the disease development. The concentration of several biochemical biomarkers changes 
significantly during the infection and the available not homogeneous data do not allow inferring at what stages the quantification of such molecules could have diagnostic/prognostic meaning. Nevertheless, it was possible to identify: i) a good correlation between abnormal blood values and chest computed tomography (CT) showing pulmonary lesions; ii) some cases of infected patients (clear symptomatology) who never resulted RNA-positive to repeated (34) RT-PCR tests and sometime had even no CT-detected lesions. Furthermore, the differential trend of some serum biomarkers between survivors and nonsurvivors might be a predictive factor (60). Serological analyses are simpler to perform because represent already the standard in most clinical sets and it would be worthy to understand whether the simultaneous analysis of combinations of serological parameters could help in decreasing the number of false-negative typical of RT-PCR-based tests performed with swabs that are difficult to recover under standardized conditions.

\section{Humoral immune response}

As it has emphasized in the previous sections, not all epidemiologically and/or clinically confirmed COVID-19 patients are RT-PCR positive throughout the infection. Li et al. (61) reported a study of 610 hospitalized patients clinically diagnosed with COVID-19 in February 2020. Only $39.5 \%$ of the patients with COVID-19 resulted positive to RT-PCR, $27.5 \%$ to the first test and further $12.5 \%$ after a second testing. Such data illustrate how critical is the necessity of integrating RNA detection with complementary diagnostic responses. The detection of specific anti-COVID-19 antibodies represents not only a diagnostic alternative, but would also elucidate the role of immunoresponse in the progression of the disease. So far the available SARS-CoV2-specific information is limited but the data gathered during the previous coronavirus epidemics (62) indicate that the $\mathrm{N}$ and $\mathrm{S}$ proteins are the major immunogenics in SARS-CoV (63). Anti-N antibodies were the first to be detected in patients but most of the neutralizing antibodies were anti-S (64). Shortcomings of immunodiagnostics have been reported and apparently they are often caused by the poor quality of the recombinant antigens (misfolding, loss of specific epitopes) used in diagnostics (62). In addition, it is known that most of the population has developed antibodies against the common cold HCoVs, some of which can cross-react against conserved epitopes of homologous proteins present in other 
coronaviruses $(65,66)$, contributing to false positive results. Since protein $\mathrm{N}$ appears being more difficult to produce and more conserved than $S$, the latter has been preferred for immunological tests. IgM detection has been considered negligible for coronavirus diagnostics because, in contrast to what generally happens with other antigens (67), its seroconversion does not clearly anticipate that of IgG and its lower specificity but higher avidity can lead to cross-reactivity and generate false positive (62). The first case of COVID-19 patient detected in Finland confirmed that also in the case of SARS-CoV2 IgG and IgM seroconversion was synchronous and IgG titer increased faster (36). The available data relative to seroconversion in SARS-CoV2-infected patients are discordant and we tried to mediate them in the graphs reported in Figure 2.

In a sample of 173 patients with clear COVID-19 symptoms, Zhao et al. (68) identified virus RNA in only $66.7 \%$ of the patients in samples collected before day- 7 and this value dropped to $45.5 \%$ after 2 weeks. Total anti-COVID-19 antibodies were recovered in less than $40 \%$ of the patients within 1-week since onset and the number rapidly increased to $100.0 \%$ a week after. At this time $\operatorname{lgM}$ were detected in $94.3 \%$ and $\lg G$ in $79.8 \%$ of the patients. The combination of RNA and antibody analysis significantly improved the diagnostic sensitivity, whereas higher antibody titers correlated with worse clinical classification. The limits of this report are that: i) it is not specified whether the class "total antibodies" corresponds only to IgG and IgM or includes further antibodies; ii) the lack of immunoresponse in some patients is probably the consequence of missing samples which were not collected at the late disease stages. In another study, the combined identification of $\operatorname{lgM}$ and IgG was evaluated by lateral-flow immunoassay. Despite the apparent insufficient sensitivity (88.6\%) and specificity (90.6\%) of the adopted method, the data resulted more consistent for diagnostic aims than the quantification of single antibody classes in a survey of a group of 397 RT-PCR-positive and 128 RT-PCR-negative COVID-19 patients (69). Blood, serum and plasma analyses performed on a small subset of samples (7) were $100 \%$ consistent. Guo et al. (17) showed that the RT-PCRpositive rate was $>90 \%$ on $1-3$ days post symptom onset, then declined to less than $80 \%$ at day six and less than $50 \%$ after day 14 , with the overall positive detection rate of $51.9 \%$ in a single RT-PCR test. The contemporary analysis of IgA, IgM and IgG was more reliable because 
covered a longer infection period and could identify cases that were classified erroneously as negative by RT-PCR (17). Similar finding were obtained in other similar cohort studies $(29,30,35,68)$. Guo et al. (17) suggest that combining RT-PCR and IgM data might be the safest minimal diagnostic set for covering the whole infection period. This indication appears somehow in contrast with the data reported above and the survey performed by Zhang et al. (44) on 16 patients that indicated that IgG has faster seroconversion and higher diagnostic reliability than $\operatorname{lgM}$. Seroconversion between day 7 and 14 was confirmed in a group of 9 patients with similar mild infection (30). In another study, the sera from 285 patients were collected, but only for 26 of them samples were available for performing complete serological analyses over the whole survey period (27 days) (70). Low antibody concentrations were detectable in one fourth of the patients already after 2-4 days after symptom onset and within $17-19$ days $100 \%$ of them developed IgG, whereas $94 \%$ were IgM-positive after $20-22$ days. The IgG response increased constantly, the IgM concentration slightly decreased in the fourth week, both IgG and IgM content was higher in more severe cases and the combination of the two measurements identified more positive cases than one single antibody in the early disease stages. The dynamic of seroconversion was very heterogeneous among patients, with different time of plateauing and seroconversion kinetics for IgG and IgM. Anti-SARS-CoV2 antibodies were detected also in some cases which either presented symptoms or were asymptomatic but in both cases negative in at least two sequential tests for viral RNA. Specifically, 7 RT-PCR negative and asymptomatic cases on 148 were IgG and/or IgM positive (70). Although this study confirmed that the combined determination of IgG and IgM contents represents a robust diagnostic tool that can be used to identify virus infection in RT-PCR negative symptomatic as well as asymptomatic (both RT-PCR positive and negative) cases, it does not clarify how many of these antibodies had neutralizing capacity and how their expression course affected the clinical response. The characterization of the epitopes recognized by the antibodies of different patients was the focus of the contribution of Okba et al. (71). The S1 domain (or its partial sequence corresponding to the receptor biding domain) appeared being the antigen that provided the most COVID-19-specific response for IgG. In this study, both IgG and IgA had seroconversion at day 10-15 for the severe cases and one week later in patients with mild symptoms. We found only a single report dealing 
specifically with asymptomatic patients (24 cases), few of them developed mild symptoms in successive periods while others had no symptom at all (55). Unluckily, the authors analyzed some serological parameters but did not quantify the immunoresponse of such cases.

\section{Identification of neutralizing antibodies}

Patient-produced neutralizing antibodies for COVID-19 have not been characterized so far at structural level but human and mouse neutralizing binders have been described for the homologue viruses SARS-CoV1 and MERS-CoV $(72,73)$. It is known that both murine and human antibody-mediated neutralization can be lost due to spike protein mutations in MERS (74). Recently, neutralizing recombinant nanobodies against both SARS-CoV1 and MERS-CoV have been isolated $(75,76)$ and monoclonal antibodies, recombinant nanobodies and mouse polyclonal sera raised against SARS-CoV1 can have neutralizing cross-activity against SARSCoV2 as well (77-79). Another SARS-CoV1/SARS-CoV2 cross-reacting monoclonal antibody selected from hybridoma culture and then totally humanized is able to bind to S protein and neutralize the virus infection by an unknown mechanism which does not involve directly the binding to ACE2 receptor, as it is the case for most of the other antibodies (80). Crossreactivity and neutralizing capacity of antibodies originally raised against SARS-CoV1 spike protein and later tested on SARS-CoV2 appear being events limited to binders that recognize specific epitopes. The production of ineffective antibodies might be the reason for which high titer does not automatically correlate with favorable disease development $(68,70)$. The potential exploitation of neutralizing antibodies for therapeutic application can be evaluated by testing the ability of sera developed in convalescent SARS-CoV1 patients to block SARSCoV2 pseudoviruses cell entry $(4,6)$. The data from very preliminary and limited studies $(6+5$ +1 cases) without controls indicate that the plasma from SARS-CoV2 recovered patients might be beneficial for patients under critical conditions (81-83) but the absence of scientifically robust reports prevents to infer conclusions relative to this therapeutic strategy.

A better understanding of what antibody parameters (IgG class, titer, recognized epitope) would be crucial for effective treatment is feasible by using pseudoviral particles carrying the SARS-CoV2 spike protein. Such material proved being a safe means to test in vitro in biosafety 
level 2 facilities the neutralization efficiency of both artificially-induced and convalescent patient serum antibodies $(84,85)$. These data contributed to the comprehension of the high neutralizing potency of naturally developed antibodies and to define the characteristics that should have vaccines for stimulating an effective response. It should be underlined that, during anti-COVID-19 vaccine evaluation, a specific care should be devoted to antibodydependent enhancement $(A D E)$ response since such condition has been already reported for some antibodies specific for the receptor-binding domain of the MERS and SARS-CoV1 spike proteins which facilitated the viral entry and the infection of immune cells (86-88). Recently, it has been suggested that, despite the difficulty of reliable in vitro testing to demonstrate ADE (89), it should be evaluated whether COVID-19 might receive ADE by means of cross-reacting antibodies developed against other coronaviruses (90).

\section{Conclusions}

The overall survey of the state-of-the-art diagnostics indicates that the exclusive identification of COVID-19 infection by means of RNA detection by RT-PCR is not sufficiently reliable. The reason of the elevated number of undetected positive cases depends on more factors. In most of the patients, the virus recovery in naso- and oropharyngeal swabs is limited to a short post-infection period. After clearance in the upper respiratory tract the virus can still accumulate in other organs but wrong sampling time and place can lead to the generation of false negative. Other sources of incertitude such as sampling modality, sensitivity differences among commercial kits and divergences in the RT-PCR protocols used in different labs, often non specialized in diagnostics, determined the collection of heterogeneous and sometime contrasting results but have been progressively removed. Now, from a technical point of view, the methods seem highly standardized. Therefore, if more attention should be paid to the sampling location and timing, positive detection rate can be improved with repeated RT-PCR testing, by combining different specimens or by using complementary detection methods. Guo et al. (17) reported the best virus detection rate (98.6\%), when an IgM ELISA assay was applied to RT-PCR negative patients. In general, the contemporary identification of IgG and IgM is meaningful since single patients have diversified humoral response and the parallel analysis can identify cases that would remain negative if only one antibody class would be 
tested. The same principle is valid when antibody detection is combined with data of RNA amplification by RT-PCR. Some datasets indicate that such integrated diagnosis can be very beneficial in the virus early diagnosis $(17,70)$. However, it must be underlined that the immunological tests need further optimization concerning the temporary windows for IgM and IgG detection and the quality of the antigens used in the analyses. In a longer-term perspective, they should be also tuned for discriminating between protective and nonprotective immune-response, for elucidating the long-term protective effect of neutralizing antibodies and possible ADE effect as well as to evaluate the immune-response in asymptomatic patients, survivors and nonsurvivors by the virus. The advantage of serum analyses is that the samples are simpler to obtain under totally standardized conditions and high-throughput analysis are performed routinely. The availability of patient sera could also enable to evaluate the potential of serological parameters for integrating the diagnosis.

More generally, the optimal diagnostic protocol seems dependent on the disease phase. Figure 1 tried to recapitulate what specimens were suitable for RT-PCR analysis according to the disease progression and Figure 2 shows the seroconversion of IgG and IgM. We tried to summarize the overall information in the scheme reported in Figure 3 that should indicate the most appropriate diagnostic approach for each infection phase according to the present set of available data.

A final consideration is that the present attempt to make a synthesis of the available diagnostic data was complicated by the fact that authors used totally heterogeneous protocols for collecting their results and this, despite the quality of each single contribution, made particularly difficult to elaborate coherent metadata and infer guidelines. We believe that this is an important conclusion of this work because indicates that future efforts should be devoted not only to improve the technical aspects of sampling and analyses, but also to standardize the design of clinical surveys.

\section{Acknowledgments}

This work was financially supported by the grants ARRS/P4-0107, ARRS/N4-0046 and ARRS/J49322 provided by the Javna agencija za raziskovalno dejavnost Republike Slovenije. 


\section{References}

1. Zhou $P$, Yang $X L$, Wang $X G$, Hu B, Zhang L, Zhang $W$, Si HR, Zhu Y, Li B, Huang CL, Chen HD, Chen J, Luo Y, Guo H, Jiang RD, Liu MQ, Chen Y, Shen XR, Wang X, Zheng XS, Zhao K, Chen QJ, Deng F, Liu LL, Yan B, Zhan FX, Wang YY, Xiao GF, Shi ZL. 2020. A pneumonia outbreak associated with a new coronavirus of probable bat origin. Nature 579:270-273.

2. Wu F, Zhao S, Yu B, Chen YM, Wang W, Song ZG, Hu Y, Tao ZW, Tian JH, Pei YY, Yuan ML, Zhang YL, Dai FH, Liu Y, Wang QM, Zheng JJ, Xu L, Holmes EC, Zhang YZ. 2020. A new coronavirus associated with human respiratory disease in China. Nature 579:265-269.

3. van Doremalen N, Miazgowicz KL, Milne-Price S, Bushmaker T, Robertson S, Scott D, Kinne J, McLellan JS, Zhu J, Munster VJ. 2014. Host species restriction of Middle East respiratory syndrome coronavirus through its receptor, dipeptidyl peptidase 4. J Virol 88:9220-9232.

4. Lan J, Ge J, Yu J, Shan S, Zhou H, Fan S, Zhang Q, Shi X, Wang Q, Zhang L, Wang X. 2020. Structure of the SARS-CoV2 spike receptor-binding domain bound to the ACE2 receptor. Nature 581:215-220.

5. Hoffmann M, Kleine-Weber H, Schroeder S, Krüger N, Herrler T, Erichsen S, Schiergens TS, Herrler G, Wu NH, Nitsche A, Müller MA, Drosten C, Pöhlmann S. 2020. SARS-CoV2 Cell Entry Depends on ACE2 and TMPRSS2 and Is Blocked by a Clinically Proven Protease Inhibitor. Cell 181:271-280.e8.

6. Wan Y, Shang J, Graham R, Baric RS, Li F. 2020. Receptor Recognition by the Novel Coronavirus from Wuhan: an Analysis Based on Decade-Long Structural Studies of SARS Coronavirus. J Virol 94:e00127-20.

7. Ou X, Liu Y, Lei X, Li P, Mi D, Ren L, Guo L, Guo R, Chen T, Hu J, Xiang Z, Mu Z, Chen X, Chen J, Hu K, Jin Q, Wang J, Qian Z. 2020. Characterization of spike glycoprotein of SARSCoV2 on virus entry and its immune cross-reactivity with SARS-CoV. Nat Commun 11:1620. 
8. Wang Q, Zhang Y, Wu L, Niu S, Song C, Zhang Z, Lu G, Qiao C, Hu Y, Yuen KY, Wang Q, Zhou H, Yan J, Qi J. 2020. Structural and functional basis of SARS-CoV2 entry by using human ACE2. Cell S0092-8674(20)30338-X.

9. Yan R, Zhang Y, Li Y, Xia L, Guo Y, Zhou Q. 2020. Structural basis for the recognition of SARS-CoV-2 by full-length human ACE2. Science 367:1444-1448.

10. Millet JK, Kien F, Cheung CY, Siu YL, Chan WL, Li H, Leung HL, Jaume M, Bruzzone R, Peiris JS, Altmeyer RM, Nal B. 2012. Ezrin interacts with the SARS coronavirus Spike protein and restrains infection at the entry stage. PLoS One 7:e49566.

11. Vankadari N, Wilce JA. 2020. Emerging WuHan (COVID-19) coronavirus: glycan shield and structure prediction of spike glycoprotein and its interaction with human CD26. Emerg Microbes Infect 9:601-604.

12. Sargiacomo C, Sotgia F, Lisanti MP. 2020. COVID-19 and chronological aging: senolytics and other anti-aging drugs for the treatment or prevention of corona virus infection? Aging 12:6511-6517.

13. Verity R, Okell LC, Dorigatti I, Winskill P, Whittaker C, Imai N, Cuomo-Dannenburg G, Thompson H, Walker PGT, Fu H, Dighe A, Griffin JT, Baguelin M, Bhatia S, Boonyasiri A, Cori A, Cucunubá Z, FitzJohn R, Gaythorpe K, Green W, Hamlet A, Hinsley W, Laydon D, Nedjati-Gilani G, Riley S, van Elsland S, Volz E, Wang H, Wang Y, Xi X, Donnelly CA, Ghani AC, Ferguson NM. 2020. Estimates of the severity of coronavirus disease 2019: a modelbased analysis. Lancet Infect Dis S1473-3099(20)30243-7.

14. Byrne AW, McEvoy D, Collins A, Hunt K, Casey M, Barber A, Butler F, Griffin J, Lane E, McAloon C, O'Brien K, Wall P, Walsh K, More S. 2020. Inferred duration of infectious period of SARS-CoV2: rapid scoping review and analysis of available evidence for asymptomatic and symptomatic COVID-19 cases. MedRxiv https://doi.org/10.1101/2020.04.25.20079889

15. Niehus R, De Salazar PM, Taylor AR, Lipsitch M. 2020. Using observational data to quantify bias of traveller-derived COVID-19 prevalence estimates in Wuhan, China. Lancet Infect Dis S1473-3099:30229-2. 
16. Richterich P. 2020. Severe underestimation of COVID-19 case numbers: effect of epidemic growth rate and test restrictions. MedRxiv https://doi.org/10.1101/2020.04.13.20064220

17. Guo L, Ren L, Yang S, Xiao M, Chang D, Yang F, Dela Cruz CS, Wang Y, Wu C, Xiao Y, Zhang L, Han L, Dang S, Xu Y, Yang Q, Xu S, Zhu H, Xu Y, Jin Q, Sharma L, Wang L, Wang J. 2020. Profiling Early Humoral Response to Diagnose Novel Coronavirus Disease (COVID-19). Clin Infect Dis ciaa310.

18. Qin C, Zhou L, Hu Z, Zhang S, Yang S, Tao Y, Xie C, Ma K, Shang K, Wang W, Tian DS. 2020. Dysregulation of immune response in patients with COVID-19 in Wuhan, China. Clin Infect Dis ciaa248.

19. Wang F, Nie J, Wang H, Zhao Q, Xiong Y, Deng L, Song S, Ma Z, Mo P, Zhang Y. 2020. Characteristics of peripheral lymphocyte subset alteration in COVID-19 pneumonia. J Infect Dis jiaa150.

20. Chen G, Wu D, Guo W, Cao Y, Huang D, Wang H, Wang T, Zhang X, Chen H, Yu H, Zhang X, Zhang M, Wu S, Song J, Chen T, Han M, Li S, Luo X, Zhao J, Ning Q. 2020. Clinical and immunological features of severe and moderate coronavirus disease 2019. J Clin Invest 130:2620-2629.

21. Lin Q, Zhu L, Ni Z, Meng H, You L. 2020. Duration of serum neutralizing antibodies for SARS-CoV2: Lessons from SARS-CoV infection. J Microbiol Immunol Infect S16841182(20)30075-X.

22. Loeffelholz MJ, Tang YW. 2020. Laboratory diagnosis of emerging human coronavirus infections - the state of the art. Emerg Microbes Infect 9:747-756.

23. Zou L, Ruan F, Huang M, Liang L, Huang $H$, Hong $Z$, Yu J, Kang $M$, Song $Y$, Xia J, Guo $Q$, Song T, He J, Yen HL, Peiris M, Wu J. 2020. SARS-CoV2 Viral Load in Upper Respiratory Specimens of Infected Patients. N Engl J Med 382:1177-1179.

24. Wang W, Xu Y, Gao R, Lu R, Han K, Wu G, Tan W. 2020. Detection of SARS-CoV2 in different types of clinical specimens. JAMA e203786.

25. WHO. 2020. Laboratory testing for coronavirus disease 2019 (COVID-19) in suspected human $\quad$ cases. Interim 2020. 
https://apps.who.int/iris/bitstream/handle/10665/331329/WHO-COVID-19-laboratory2020.4-eng.pdf. Downloaded on April 22 ${ }^{\text {nd }}$.

26. CDC. https://www.cdc.gov/coronavirus/2019-nCoV/lab/guidelines-clinicalspecimens.html. Downloaded on May $4^{\text {th }}$.

27. Discharge criteria for confirmed COVID-19 cases, ECDC TECHNICAL REPORT, 10 Mar 2020. https://www.ecdc.europa.eu/sites/default/files/documents/COVID-19-Dischargecriteria.pdf Downloaded on April 24 $4^{\text {th }}$.

28. Yang Y, Yang M, Shen C, Wang F, Yuan J, Li J, Zhang M, Wang Z, Xing L, Wei J, Peng L, Wong G, Zheng H, Liao M, Feng K, Li J, Yang Q, Zhao J, Zhang Z, Liu L, Liu Y. 2020. Evaluating the accuracy of different respiratory specimens in the laboratory diagnosis and monitoring the viral shedding of 2019-nCoV infections. MedRxiv https://doi.org/10.1101/2020.02.11.20021493

29. Zheng S, Fan J, Yu F, Feng B, Lou B, Zou Q, Xie G, Lin S, Wang R, Yang X, Chen W, Wang Q, Zhang D, Liu Y, Gong R, Ma Z, Lu S, Xiao Y, Gu Y, Zhang J, Yao H, Xu K, Lu X, Wei G, Zhou J, Fang Q, Cai H, Qiu Y, Sheng J, Chen Y, Liang T. 2020. Viral load dynamics and disease severity in patients infected with SARS-CoV2 in Zhejiang province, China, January-March 2020: retrospective cohort study. BMJ 369:m1443.

30. Wölfel R, Corman VM, Guggemos W, Seilmaier M, Zange S, Müller MA, Niemeyer D, Jones TC, Vollmar P, Rothe C, Hoelscher M, Bleicker T, Brünink S, Schneider J, Ehmann R, Zwirglmaier K, Drosten C, Wendtner C. 2020. Virological assessment of hospitalized patients with COVID-2019. Nature doi: 10.1038/s41586-020-2196-x.

31. Drosten C, Chiu LL, Panning M, Leong HN, Preiser W, Tam JS, Günther S, Kramme S, Emmerich P, Ng WL, Schmitz H, Koay ES. 2004. Evaluation of advanced reverse transcription-PCR assays and an alternative PCR target region for detection of severe acute respiratory syndrome associated coronavirus. J Clin Microbiol 42:2043-2047.

32. Peiris JS, Chu CM, Cheng VC, Chan KS, Hung IF, Poon LL, Law KI, Tang BS, Hon TY, Chan CS, Chan KH, Ng JS, Zheng BJ, Ng WL, Lai RW, Guan Y, Yuen KY, HKU/UCH SARS Study Group. 2003. Clinical progression and viral load in a community outbreak of coronavirusassociated SARS pneumonia: a prospective study. Lancet 361:1767-1772. 
33. To KK, Tsang OT, Chik-Yan Yip C, Chan KH, Wu TC, Chan JMC, Leung WS, Chik TS, Choi CY, Kandamby DH, Lung DC, Tam AR, Poon RW, Fung AY, Hung IF, Cheng VC, Chan JF, Yuen KY. 2020. Consistent detection of 2019 novel coronavirus in saliva. Clin Infect Dis ciaa149.

34. Patel R, Babady E, Theel ES, Storch GA, Pinsky BA, St. George K, Smith TC, Bertuzzi S. 2020. Report from the American Society for Microbiology COVID-19 International Summit, 23 March 2020: Value of diagnostic testing for SARS-CoV-2/COVID-19. mBio 11:e00722-20.

35. Yongchen Z, Shen H, Wang X, Shi X, Li Y, Yan J, Chen Y, Gu B. 2020. Different longitudinal patterns of nucleic acid and serology testing results based on disease severity of COVID19 patients. Emerg Microbes Infect 9:833-836.

36. Haveri A, Smura T, Kuivanen S, Österlund P, Hepojoki J, Ikonen N, Pitkäpaasi M, Blomqvist S, Rönkkö E, Kantele A, Strandin T, Kallio-Kokko H, Mannonen L, Lappalainen M, Broas M, Jiang M, Siira L, Salminen M, Puumalainen T, Sane J, Melin M, Vapalahti O, SavolainenKopra C. 2020. Serological and molecular findings during SARS-CoV2 infection: the first case study in Finland, January to February 2020. Euro Surveill 25:2000266.

37. Huang C, Wang Y, Li X, Ren L, Zhao J, Hu Y, Zhang L, Fan G, Xu J, Gu X, Cheng Z, Yu T, Xia J, Wei Y, Wu W, Xie X, Yin W, Li H, Liu M, Xiao Y, Gao H, Guo L, Xie J, Wang G, Jiang R, Gao Z, Jin Q, Wang J, Cao B. 2020. Clinical features of patients infected with 2019 novel coronavirus in Wuhan, China. Lancet 395:497-506.

38. Chen W, Lan Y, Yuan X, Deng X, Li Y, Cai X, Li L, He R, Tan Y, Deng X, Gao M, Tang G, Zhao L, Wang J, Fan Q, Wen C, Tong Y, Tang Y, Hu F, Li F, Tang X. 2020. Detectable 2019-nCoV viral RNA in blood is a strong indicator for the further clinical severity. Emerg Microbes Infect 9:469-473.

39. Peng L, Liu J, Xu W, Luo Q, Chen D, Lei Z, Huang Z, Li X, Deng K, Lin B, Gao Z. 2020. SARSCoV2 can be detected in urine, blood, anal swabs, and oropharyngeal swabs specimens. J Med Virol doi: 10.1002/jmv.25936.

40. Ozma MA, Maroufi P, Khodadadi E, Köse Ş, Esposito I, Ganbarov K, Dao S, Esposito S, Dal T, Zeinalzadeh E, Kafil HS. 2020. Clinical manifestation, diagnosis, prevention and control of SARS-CoV2 (COVID-19) during the outbreak period. Infez Med 28:153-165. 
41. Wu Y, Guo C, Tang L, Hong Z, Zhou J, Dong X, Yin H, Xiao Q, Tang Y, Qu X, Kuang L, Fang X, Mishra N, Lu J, Shan H, Jiang G, Huang X. 2020. Prolonged presence of SARS-CoV-2 viral RNA in faecal samples. Lancet Gastroenterol Hepatol 5:434-435.

42. Holshue ML, DeBolt C, Lindquist S, Lofy KH, Wiesman J, Bruce H, Spitters C, Ericson K, Wilkerson S, Tural A, Diaz G, Cohn A, Fox L, Patel A, Gerber SI, Kim L, Tong S, Lu X, Lindstrom S, Pallansch MA, Weldon WC, Biggs HM, Uyeki TM, Pillai SK, Washington State 2019-nCoV Case Investigation Team. 2020. First case of 2019 novel coronavirus in the United States. N Engl J Med 382:929-936.

43. Zhang T, Cui X, Zhao X, Wang J, Zheng J, Zheng G, Guo W, Cai C, He S, Xu Y. 2020. Detectable SARS-CoV2 viral RNA in feces of three children during recovery period of COVID-19 pneumonia. J Med Virol doi: 10.1002/jmv.25795.

44. Zhang W, Du RH, Li B, Zheng XS, Yang XL, Hu B, Wang YY, Xiao GF, Yan B, Shi ZL, Zhou P. 2020. Molecular and serological investigation of 2019-nCoV infected patients: implication of multiple shedding routes. Emerg Microbes Infect 9:386-389.

45. Zhu N, Zhang D, Wang W, Li X, Yang B, Song J, Zhao X, Huang B, Shi W, Lu R, Niu P, Zhan F, Ma X, Wang D, Xu W, Wu G, Gao GF, Tan W, China Novel Coronavirus Investigating and Research Team. 2020. A Novel Coronavirus from patients with pneumonia in China, 2019. N Engl J Med 382:727-733.

46. Lu R, Zhao X, Li J, Niu P, Yang B, Wu H, Wang W, Song H, Huang B, Zhu N, Bi Y, Ma X, Zhan F, Wang L, Hu T, Zhou H, Hu Z, Zhou W, Zhao L, Chen J, Meng Y, Wang J, Lin Y, Yuan J, Xie Z, Ma J, Liu WJ, Wang D, Xu W, Holmes EC, Gao GF, Wu G, Chen W, Shi W, Tan W. 2020. Genomic characterisation and epidemiology of 2019 novel coronavirus: implications for virus origins and receptor binding. Lancet 30:30251-30258.

47. Ahn DG, Shin HJ, Kim MH, Lee S, Kim HS, Myoung J, Kim BT, Kim SJ. 2020. Current Status of Epidemiology, Diagnosis, Therapeutics, and Vaccines for Novel Coronavirus Disease 2019 (COVID-19). J Microbiol Biotechnol 30:313-324.

48. Corman VM, Landt O, Kaiser M, Molenkamp R, Meijer A, Chu DK, Bleicker T, Brünink S, Schneider J, Schmidt ML, Mulders DG, Haagmans BL, van der Veer B, van den Brink S, Wijsman L, Goderski G, Romette JL, Ellis J, Zambon M, Peiris M, Goossens H, Reusken C, 
Koopmans MP, Drosten C. 2020. Detection of 2019 novel coronavirus (2019-nCoV) by real-time RT-PCR. Euro Surveill 25:2000045.

49. Shear MD, Goodnough A, Kaplan S, Fink S, Thomas K, Weiland N. 2020. The lost month: how a failure to test blinded the US to Covid-19. The New York Times, March $28^{\text {th }}$, updated April $1^{\text {st }}$. https://www.nytimes.com/2020/03/28/us/testing-coronaviruspandemic.html Downloaded on May $12^{\text {th }}$.

50. Konrad R, Eberle U, Dangel A, Treis B, Berger A, Bengs K, Fingerle V, Liebl B, Ackermann N, Sing A. 2020. Rapid establishment of laboratory diagnostics for the novel coronavirus SARS-CoV-2 in Bavaria, Germany, February 2020. Euro Surveill 25:2000173.

51. Chan JF, Yip CC, To KK, Tang TH, Wong SC, Leung KH, Fung AY, Ng AC, Zou Z, Tsoi HW, Choi GK, Tam AR, Cheng VC, Chan KH, Tsang OT, Yuen KY. 2020. Improved molecular diagnosis of COVID-19 by the novel, highly sensitive and specific COVID-19-RdRp/Hel Real-Time Reverse Transcription-PCR assay validated in vitro and with clinical specimens. J Clin Microbiol 58:e00310-20.

52. Wang M, Wu Q, Xu W, Qiao B, Wang J, Zheng H, Jiang S, Mei J, Wu Z, Deng Y, Zhou F, Wu W, Zhang Y, Lv Z, Huang J, Guo X, Feng L, Xia Z, Li D, Xu Z, Liu T, Zhang P, Tong Y, Li Y. 2020. Clinical diagnosis of 8274 samples with 2019-novel coronavirus in Wuhan. MedRxiv https://doi.org/10.1101/2020.02.12.20022327

53. Chan JF, Yuan S, Kok KH, To KK, Chu H, Yang J, Xing F, Liu J, Yip CC, Poon RW, Tsoi HW, Lo SK, Chan KH, Poon VK, Chan WM, Ip JD, Cai JP, Cheng VC, Chen H, Hui CK, Yuen KY. 2020. A familial cluster of pneumonia associated with the 2019 novel coronavirus indicating person-to-person transmission: a study of a family cluster. Lancet 395:514-523.

54. Pfefferle S, Reucher S, Nörz D, Lütgehetmann M. 2020. Evaluation of a quantitative RTPCR assay for the detection of the emerging coronavirus SARS-CoV-2 using a high throughput system. Euro Surveill 25:2000152.

55. Hu Z, Song C, Xu C, Jin G, Chen Y, Xu X, Ma H, Chen W, Lin Y, Zheng Y, Wang J, Hu Z, Yi Y, Shen H. 2020. Clinical characteristics of 24 asymptomatic infections with COVID-19 screened among close contacts in Nanjing, China. Sci China Life Sci doi: 10.1007/s11427020-1661-4. 
56. Wan S, Yi Q, Fan S, Lv J, Zhang X, Guo L, Lang C, Xiao Q, Xiao K, Yi Z, Qiang M, Xiang J, Zhang B, Chen Y. 2020. Characteristics of lymphocyte subsets and cytokines in peripheral blood of 123 hospitalized patients with 2019 novel coronavirus pneumonia (NCP). MedRxiv https://doi.org/10.1101/2020.02.10.20021832

57. Liu Y, Yang Y, Zhang C, Huang F, Wang F, Yuan J, Wang Z, Li J, Li J, Feng C, Zhang Z, Wang L, Peng L, Chen L, Qin Y, Zhao D, Tan S, Yin L, Xu J, Zhou C, Jiang C, Liu L. 2020. Clinical and biochemical indexes from 2019-nCoV infected patients linked to viral loads and lung injury. Sci China Life Sci 63:364-374.

58. Guan WJ, Ni ZY, Hu Y, Liang WH, Ou CQ, He JX, Liu L, Shan H, Lei CL, Hui DSC, Du B, Li L, Zeng G, Yuen KY, Chen RC, Tang CL, Wang T, Chen PY, Xiang J, Li SY, Wang JL, Liang ZJ, Peng YX, Wei L, Liu Y, Hu YH, Peng P, Wang JM, Liu JY, Chen Z, Li G, Zheng ZJ, Qiu SQ, Luo J, Ye CJ, Zhu SY, Zhong NS, China Medical Treatment Expert Group for COVID-19. 2020. Clinical characteristics of coronavirus disease 2019 in China. N Engl J Med 382:1708-1720. 59. Zhang JJ, Dong X, Cao YY, Yuan YD, Yang YB, Yan YQ, Akdis CA, Gao YD. 2020. Clinical characteristics of 140 patients infected with SARS-CoV2 in Wuhan, China. Allergy doi: 10.1111/all.14238.

60. Wang D, Hu B, Hu C, Zhu F, Liu X, Zhang J, Wang B, Xiang H, Cheng Z, Xiong Y, Zhao Y, Li Y, Wang X, Peng Z. 2020. Clinical characteristics of 138 hospitalized patients with 2019 novel coronavirus-infected pneumonia in Wuhan, China. JAMA 323:1061-1069.

61. Li Y, Yao L, Li J, Chen L, Song Y, Cai Z, Yang C. 2020. Stability issues of RT-PCR testing of SARS-CoV-2 for hospitalized patients clinically diagnosed with COVID-19. J Med Virol doi: $10.1002 / j m v .25786$.

62. Meyer B, Drosten C, Müller MA. 2014. Serological assays for emerging coronaviruses: challenges and pitfalls. Virus Res 194:175-183.

63. Qiu M, Shi Y, Guo Z, Chen Z, He R, Chen R, Zhou D, Dai E, Wang X, Si B, Song Y, Li J, Yang L, Wang J, Wang H, Pang X, Zhai J, Du Z, Liu Y, Zhang Y, Li L, Wang J, Sun B, Yang R. 2005. Antibody responses to individual proteins of SARS coronavirus and their neutralization activities. Microbes Infect 7:882-889.

64. Woo PC, Lau SK, Wong BH, Tsoi HW, Fung AM, Kao RY, Chan KH, Peiris JS, Yuen KY. 2005. Differential sensitivities of severe acute respiratory syndrome (SARS) coronavirus spike 
polypeptide enzyme-linked immunosorbent assay (ELISA) and SARS coronavirus nucleocapsid protein ELISA for serodiagnosis of SARS coronavirus pneumonia. J Clin Microbiol 43:3054-3058.

65. Chen Z, Pei D, Jiang L, Song Y, Wang J, Wang H, Zhou D, Zhai J, Du Z, Li B, Qiu M, Han Y, Guo Z, Yang R. 2004. Antigenicity analysis of different regions of the severe acute respiratory syndrome coronavirus nucleocapsid protein. Clin Chem 50:988-995.

66. He Y, Zhou Y, Wu H, Luo B, Chen J, Li W, Jiang S. 2004. Identification of immunodominant sites on the spike protein of severe acute respiratory syndrome (SARS) coronavirus: implication for developing SARS diagnostics and vaccines. J Immunol 173:4050-4057.

67. Woo PC, Lau SK, Wong BH, Chan KH, Chu CM, Tsoi HW, Huang Y, Peiris JS, Yuen KY. 2004. Longitudinal profile of immunoglobulin G (IgG), IgM, and IgA antibodies against the severe acute respiratory syndrome (SARS) coronavirus nucleocapsid protein in patients with pneumonia due to the SARS coronavirus. Clin Diagn Lab Immunol 11:665-668.

68. Zhao J, Yuan Q, Wang H, Liu W, Liao X, Su Y, Wang X, Yuan J, Li T, Li J, Qian S, Hong C, Wang F, Liu Y, Wang Z, He Q, Li Z, He B, Zhang T, Fu Y, Ge S, Liu L, Zhang J, Xia N, Zhang Z. 2020. Antibody responses to SARS-CoV-2 in patients of novel coronavirus disease 2019. Clin Infect Dis ciaa344.

69. Li Z, Yi Y, Luo X, Xiong N, Liu Y, Li S, Sun R, Wang Y, Hu B, Chen W, Zhang Y, Wang J, Huang B, Lin Y, Yang J, Cai W, Wang X, Cheng J, Chen Z, Sun K, Pan W, Zhan Z, Chen L, Ye F. 2020. Development and clinical application of a rapid IgM-IgG combined antibody test for SARSCoV-2 infection diagnosis. J Med Virol doi: 10.1002/jmv.25727.

70. Long QX, Liu BZ, Deng HJ, Wu GC, Deng K, Chen YK, Liao P, Qiu JF, Lin Y, Cai XF, Wang DQ, Hu Y, Ren JH, Tang N, Xu YY, Yu LH, Mo Z, Gong F, Zhang XL, Tian WG, Hu L, Zhang XX, Xiang JL, Du HX, Liu HW, Lang CH, Luo XH, Wu SB, Cui XP, Zhou Z, Zhu MM, Wang J, Xue CJ, Li XF, Wang L, Li ZJ, Wang K, Niu CC, Yang QJ, Tang XJ, Zhang Y, Liu XM, Li JJ, Zhang DC, Zhang F, Liu P, Yuan J, Li Q, Hu JL, Chen J, Huang AL. 2020. Antibody responses to SARSCoV-2 in patients with COVID-19. Nat Med doi: 10.1038/s41591-020-0897-1.

71. Okba NMA, Müller MA, Li W, Wang C, GeurtsvanKessel CH, Corman VM, Lamers MM, Sikkema RS, de Bruin E, Chandler FD, Yazdanpanah Y, Le Hingrat Q, Descamps D, HouhouFidouh N, Reusken CBEM, Bosch BJ, Drosten C, Koopmans MPG, Haagmans BL. 2020. 
Severe Acute Respiratory Syndrome Coronavirus 2-Specific Antibody Responses in Coronavirus Disease 2019 Patients. Emerg Infect Dis 26. doi: 10.3201/eid2607.200841.

72. Hwang WC, Lin Y, Santelli E, Sui J, Jaroszewski L, Stec B, Farzan M, Marasco WA, Liddington RC. 2006. Structural basis of neutralization by a human anti-severe acute respiratory syndrome spike protein antibody, 80R. J Biol Chem 281:34610-34616.

73. Wang L, Shi W, Chappell JD, Joyce MG, Zhang Y, Kanekiyo M, Becker MM, van Doremalen N, Fischer R, Wang N, Corbett KS, Choe M, Mason RD, Van Galen JG, Zhou T, Saunders KO, Tatti KM, Haynes LM, Kwong PD, Modjarrad K, Kong WP, McLellan JS, Denison MR, Munster VJ, Mascola JR, Graham BS. 2018. Importance of neutralizing monoclonal antibodies targeting multiple antigenic sites on the Middle East Respiratory Syndrome Coronavirus spike glycoprotein to avoid neutralization escape. J Virol 92:e02002-17.

74. Kleine-Weber H, Elzayat MT, Wang L, Graham BS, Müller MA, Drosten C, Pöhlmann S, Hoffmann M. 2019. Mutations in the spike protein of Middle East Respiratory Syndrome coronavirus transmitted in Korea increase resistance to antibody-mediated neutralization. J Virol 93:e01381-18.

75. Stalin Raj V, Okba NMA, Gutierrez-Alvarez J, Drabek D, van Dieren B, Widagdo W, Lamers MM, Widjaja I, Fernandez-Delgado R, Sola I, Bensaid A, Koopmans MP, Segalés J, Osterhaus ADME, Bosch BJ, Enjuanes L, Haagmans BL. 2018. Chimeric camel/human heavy-chain antibodies protect against MERS-CoV infection. Sci Adv 4:eaas9667.

76. Zhao G, He L, Sun S, Qiu H, Tai W, Chen J, Li J, Chen Y, Guo Y, Wang Y, Shang J, Ji K, Fan R, Du E, Jiang S, Li F, Du L, Zhou Y. 2018. A novel nanobody targeting Middle East Respiratory Syndrome Coronavirus (MERS-CoV) receptor-binding domain has potent cross-neutralizing activity and protective efficacy against MERS-CoV. J Virol 92:e0083718.

77. Tian X, Li C, Huang A, Xia S, Lu S, Shi Z, Lu L, Jiang S, Yang Z, Wu Y, Ying T. 2020. Potent binding of 2019 novel coronavirus spike protein by a SARS coronavirus-specific human monoclonal antibody. Emerg Microbes Infect 9:382-385.

78. Wrapp D, De Vlieger D, Corbett KS, Torres GM, Wang N, Van Breedam W, Roose K, van Schie L; VIB-CMB COVID-19 Response Team, Hoffmann M, Pöhlmann S, Graham BS, Callewaert N, Schepens B, Saelens X, McLellan JS. 2020. Structural basis for potent 
neutralization of betacoronaviruses by single-domain camelid antibodies. Cell S00928674(20)30494-3.

79. Walls AC, Park YJ, Tortorici MA, Wall A, McGuire AT, Veesler D. 2020. Structure, Function, and Antigenicity of the SARS-CoV2 Spike Glycoprotein. Cell 181:281-292.e6.

80. Wang C, Li W, Drabek D, Okba NMA, van Haperen R, Osterhaus ADME, van Kuppeveld FJM, Haagmans BL, Grosveld F, Bosch BJ. 2020. A human monoclonal antibody blocking SARS-CoV2 infection. Nat Commun 11:2251.

81. Ye M, Fu D, Ren Y, Wang F, Wang D, Zhang F, Xia X, Lv T. 2020. Treatment with convalescent plasma for COVID-19 patients in Wuhan, China. J Med Virol doi: 10.1002/jmv.25882.

82. Shen C, Wang Z, Zhao F, Yang Y, Li J, Yuan J, Wang F, Li D, Yang M, Xing L, Wei J, Xiao H, Yang Y, Qu J, Qing L, Chen L, Xu Z, Peng L, Li Y, Zheng H, Chen F, Huang K, Jiang Y, Liu D, Zhang Z, Liu Y, Liu L. 2020. Treatment of 5 Critically III Patients With COVID-19 With Convalescent Plasma. JAMA 323:1582-1589.

83. Zhang L, Pang R, Xue X, Bao J, Ye S, Dai Y, Zheng Y, Fu Q, Hu Z, Yi Y. 2020. Anti-SARS-CoV2 virus antibody levels in convalescent plasma of six donors who have recovered from COVID-19. Aging 12:6536-6542.

84. Pu T, Ding C, Li Y, Liu X, Li H, Duan J, Zhang H, Bi Y, Cun W. 2020. Evaluate severe acute respiratory syndrome coronavirus 2 infectivity by pseudoviral particles. J Med Virol doi: $10.1002 / j m v .25865$.

85. Nie J, Li Q, Wu J, Zhao C, Hao H, Liu H, Zhang L, Nie L, Qin H, Wang M, Lu Q, Li X, Sun Q, Liu J, Fan C, Huang W, Xu M, Wang Y. 2020. Establishment and validation of a pseudovirus neutralization assay for SARS-CoV2. Emerg Microbes Infect 9:680-686.

86. Yang ZY, Werner HC, Kong WP, Leung K, Traggiai E, Lanzavecchia A, Nabel GJ. 2005. Evasion of antibody neutralization in emerging severe acute respiratory syndrome coronaviruses. Proc Natl Acad Sci USA 102:797-801.

87. Yip MS, Leung NH, Cheung CY, Li PH, Lee HH, Daëron M, Peiris JS, Bruzzone R, Jaume M. 2014. Antibody-dependent infection of human macrophages by severe acute respiratory syndrome coronavirus. Virol J 11:82. 
88. Wan Y, Shang J, Sun S, Tai W, Chen J, Geng Q, He L, Chen Y, Wu J, Shi Z, Zhou Y, Du L, Li F. 2020. Molecular mechanism for Antibody-Dependent Enhancement of coronavirus entry. J Virol 94:e02015-19.

89. Sharma A. 2020. It is too soon to attribute ADE to COVID-19. Microbes Infect S12864579(20)30051-4.

90. Tetro JA. 2020. Is COVID-19 receiving ADE from other coronaviruses? Microbes Infect 22:72-73. 


\section{Figure legends}

Figure 1. Temporal development of viral RNA detection in different biological samples

The SARS-CoV2 virus concentrations in different organisms and, consequently, corresponding specimens, changes during the disease development. Accordingly, RT-PCR should be performed choosing the most appropriate sample for that specific infection phase

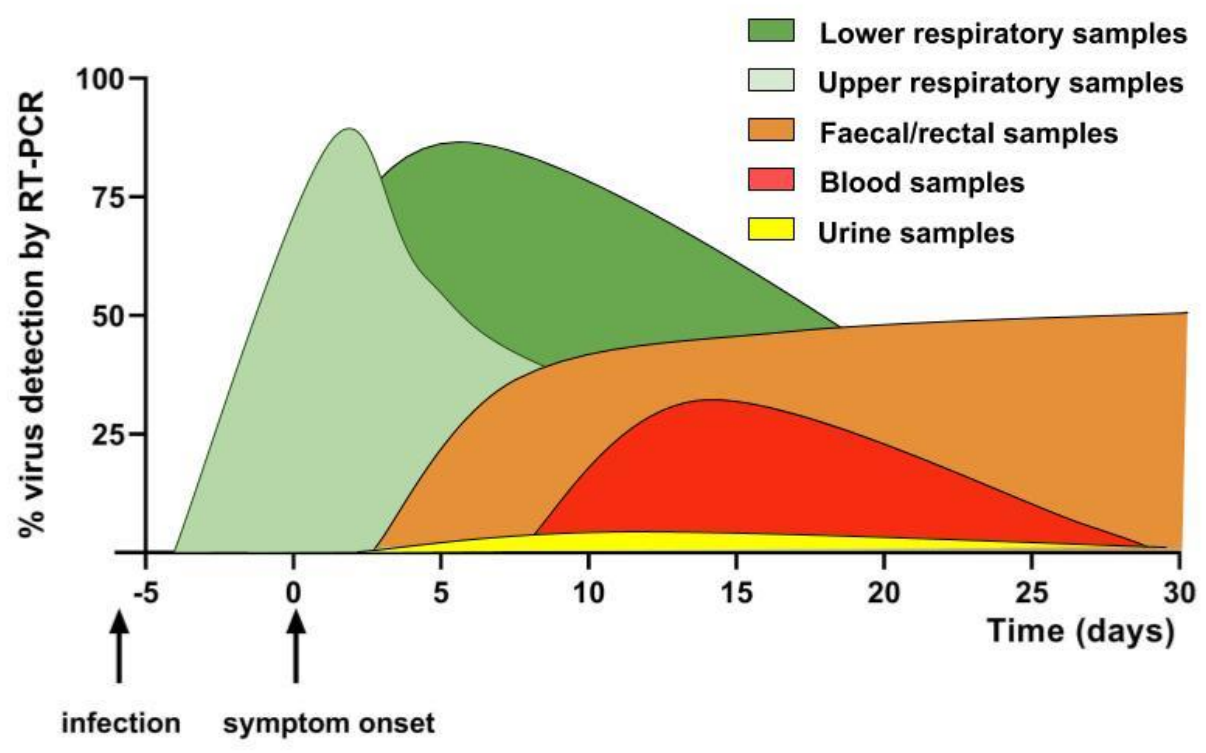

Figure 2. Immunoconversion pattern of anti-SARS-CoV2 IgM and IgG

The dynamic of antibody immunoconversion is patient-specific but the available data indicate that it takes place roughly 7 days after symptoms onset and is almost contemporary for IgG and IgM. Since IgG and IgM develop independently in different patients, the contemporary analysis of both antibody types has a synergistic effect 


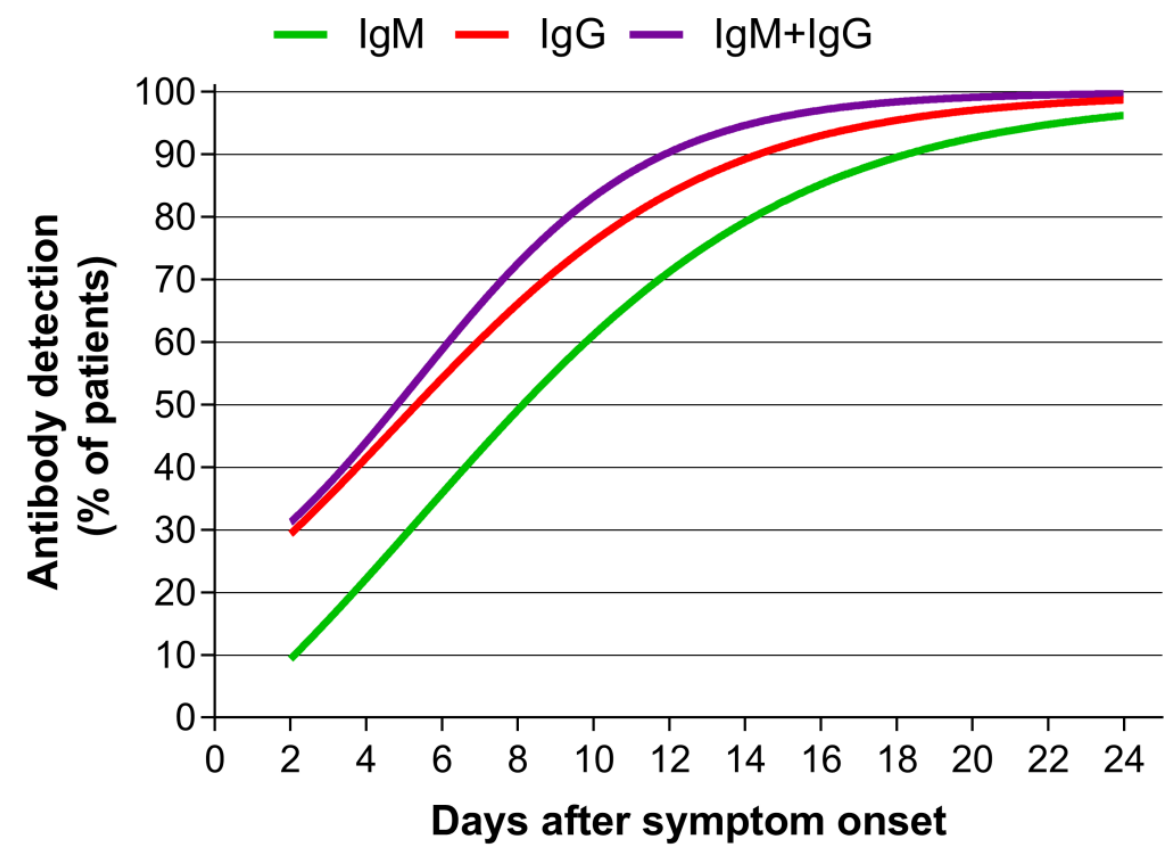

Figure 3. Time-dependent COVID-19 diagnostics by combined molecular and serologic tests

Each COVID-19 phase would require an optimal (minimal) mix of diagnostic tests. The longterm antibody persistency can be inferred by the data available for patient antibodies directed against SARS-CoV1 and MERS

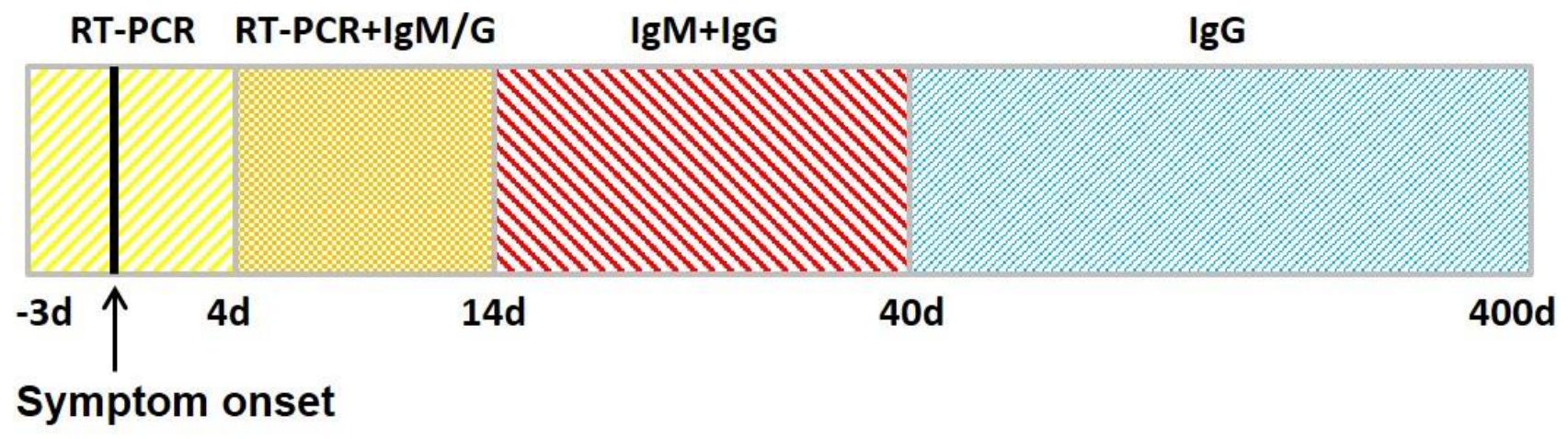

